Trivent Publishing

(C) The Authors, 2016

Available online at http://trivent-publishing.eu/

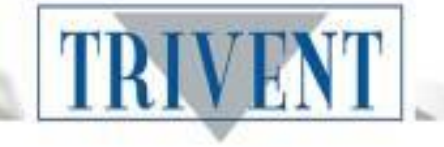

Series: Philosophy, Communication, Media Sciences

Volume: Communication Today: An Overview from Online Journalism to Applied Philosophy

\title{
Philocaly as Ground for Philosophical Practice in Augustine
}

\author{
Claudiu Mesaroș \\ West University of Timișoara, Romania \\ Centre for Research in Historiography of Philosophy and Philosophy of Imaginary \\ claudiu.mesaros@e-uvt.ro
}

\begin{abstract}
Augustine's opinion on the conditions one must fulfil in order to be able to understand and practice philosophy, namely to become a philosopher, depend on his use of a comparison between philocaly and philosophy that he may have learnt from the platonic tradition. In his Contra academicos and De ordine he discusses these terms showing that philocaly refers to a love for trivial beautiful things that can be coverted into a love for authentic beautiful things, and finally this will be converted into the love for wisdom or philosophy by liberal arts. There are three stages of love for beauty: love for the trivial beauty, educated love for attested beautiful things, and love for beauty understood as wisdom. Augustine applies this discussion to his friends and dialogue partners, Licentius and Romanianus, making it a subject of practical philosophy or philosophy as a program for life.
\end{abstract}

\section{Keywords:}

Augustine, Plato, philocaly, philosophy, scala amoris, beauty, gift, happiness, wisdom, liberal arts

This is an Open Access article distributed in accordance with the Creative Commons Attribution Non Commercial (CC-BY-NCND 4.0) license, which permits others to copy or share the article, provided original work is properly cited and that this is not done for commercial purposes. Users may not remix, transform, or build upon the material and may not distribute the modified material (http://creativecommons.org/licenses/by-nc/4.0/)

DOI: $10.22618 /$ TP.PCMS.20164.349025 


\section{Introduction}

The tradition of attributing the name Philocaly to the ascetic works is very old, but incomplete. The origins of this tradition are philosophical and the primary meaning is aesthetic rather than moral; it originally refers to the love of beauty, or love for beautiful and precious things. It is a kind of love for something special, although the reasons why certain object is said to be beautiful or precious are not always clearly defined. That is why the lover of beauty, in this original signification, is rather an amateur than a connoisseur, maybe even an "amateur of ornaments,"1 as Xenophon named child Cyrus (philokalos kai philotymos). ${ }^{2}$ Philokalos could also mean ambitious, virtuous, noble, courageous, and generous. The Athenians, as Pericle said, have these two features among many: the love of beauty, philokalia, and the love of knowledge, philosophia ("For we are lovers of beauty yet with no extravagance and lovers of wisdom yet without weakness."). ${ }^{3}$ But could we say that the road to philosophy is a mere sentimentality, a random entrance on a personal orbit, whose choice is somewhat indifferent? What would this option mean, how can we tie the encounter with philosophy with the unstable ground of the affects?

\section{Platonic background}

Love of beauty, taken in this sense, is finally followed by the prôton philon, as Plato said, love in its prime or paradigmatic sense, the sublime instance of love exempted by the indecision of the juvenile desire, the unskillful search for a vague good, longing for power, as Plato in his dialectic excursus conceptualized the stages of the Eros. ${ }^{4}$ Of Eros or immature love is to be talked about in many ways because it is plural and unstable, having a many states and instances: it is a relationship rather than anything else, an intermediate nature, just like the act of searching itself; it is neither a god nor a demon, neither beautiful nor ugly, neither wealthy nor poor. It is so precisely because it is, for that matter, rather nothing than anything, more like an interval than a limit; this act of search called Eros tragically goes through a destiny which, taking the form of an ascension (scala amoris), is fulfilled in a natural and practical telos, a primordial state in which the person is transformed. This scale of erotic life is organized in an ascending fashion: it starts with looking for beautiful bodies, specific for juvenile unrest, then follows the understanding of the unity of beauty (giving up repetition or series), followed in turn by the love for all beautiful bodies, that is actually non-corporeal but aesthetic; then the love of souls comes, which exceeds the aesthetic stage, then there is the love of the beauty within the souls (laws, knowledge, skills, harmonies), followed by the love of truth specific to sciences; finally, the ultimate step is the love of beauty in itself, prôton philon, a special science, knowledge of beauty itself. ${ }^{5}$

Philosophy and Philocaly are, in this sense, equally practical engagements depending on wisdom and beauty, more precisely on love of beauty in itself. Love as a purpose must be considered in a most practical meaning, and this is where we can find the connection between philosophy and philocaly: both are ways of life.

\footnotetext{
${ }^{1}$ Paul Florenski, La colonne et le fondement de la vérité, traduit du russe par Constantin Andronikof (Paris: L’Âge d'homme, 1975), 415-416, footnote 34.

2 Xenophon, "Cyropaedia," in Xenophon in Seven Volumes, ed. Walter Miller (Cambridge: Harvard University Press, 1914), 1.3.3: "and as Cyrus was a boy fond of beautiful things and eager for distinction (philotymos), he was pleased with his dress and greatly delighted at learning to ride", translation by Walter Miller.

${ }^{3}$ See: Thucydides, History of the Peloponnesian War, ed. Benjamin Jowett, Perseus Project. II.40: "Philokalomen te gar meth auteleias kai philosophoumen aneu malakias."

${ }^{4}$ Plato, "Symposium," in Plato, Complete Works (Indianapolis: Hackett Publishing, 1997), 209e-210e.

5 Plato, "Symposium," in Plato, Complete Works (Indianapolis: Hackett Publishing, 1997), $210 \mathrm{e}$.
} 


\section{A gift from Augustine}

A certain foundation or perhaps only similar justification of philosophy starting from our soul's emotional function was proposed by Augustine, in a context in which he spoke exactly about the relationship between philosophy and philocaly, in a very special way.

In Contra academicos he was counselling Romanianus towards practicing philosophy, proposing therefore a protreptikos-like type undertaking, having as thematic pretext certainty and overcoming the scepticism of the New Academy. Happiness lies within knowing the truth, Augustine asserted there, building a speech based on personal example and anchoring the call to philosophy on the personal traits of the interlocutor, recognizing the moral and material role of Romanianus in his life. Thus, he praises him for his unconditional friendship and his natural qualities, which appear as a sort of natural condition of practicing philosophy, and therefore encourages him to commit to the chase for wisdom; that is, properly speaking, a restructuration or rather reordering of the desires to their natural condition: "Shall I not fully repay your favours to me? Do I perhaps owe you a very little? When I was an impoverished young man setting out on my studies away from home, you welcomed me into your house, into your munificence, and, what is much more, into your spirit. You comforted me with your friendship when I lost my father, encouraged me with your counsel, and helped me with your wealth. You made me nearly as renowned and important in our own town as yourself by your patronage, familiarity, and reception of me in your home. You alone were the pone, when I returned to Carthage to get a more advantageous position, to whom I confided my plan and my hopes, notlanyone in my family. Though you hesitated for a little while there, when you weren't able to overcome a young man's ambition into support, with admirable self-control ..."7

The fragment above started with a vigorous invitation to practice philosophy ("Therefore, come with me to philosophy. In nit there is everything that is wont to move you wonderfully whenever you're anxious and thrown into doubt..."), ${ }^{8}$ which is being introduced as the greatest gift Augustine was able to offer to Romanianus in returns for his past favours to him: „fortune would seem good to me except what would provide leisure for doing philosophy, and that no life would seem happy except one in which I might live in philosophy. ... You were elevated by so great a joy, so inflamed by a holy zeal for this kind of life, that you told me that if you could somehow extricate yourself from the chains of your troublesome lawsuits you would break all the chains holding me, even to the extent of sharing your patrimony with me." 9

The protreptikos endeavoured by Augustine here is intended for the human qualities of a particular individual that are well enough familiar to the philosopher, certainly not for an abstract public. The call for philosophy is actually a gift, perhaps the most generous possible ever: philosophy offers us the best fate, so the person that provides guidance into philosophy is also answering to an equivalent generosity, which can be symbolized or replenished in material order through "sharing your patrimony." ${ }^{10}$ Romanianus has helped Augustine materially (see as well Confessions 6.14.24) is very close and dear to Augustine.

Such excerpts show that the practice of philosophy implies the existence and conduct of certain qualities or natural resources of the philosopher: an inner light that shines through in our lives no matter the vices that we may give into occasionally. There are so to say certain natural predeterminations, or conditions of possibility for us to be attracted into the search for beauty. These are indeed able to be

\footnotetext{
${ }^{6}$ See: Mark J. Boone, The Conversion and Therapy of Desire in Augustine's Cassiciacum Dialogues. (Umi Dissertation Publishing Proquest, 2011), XXXX. available at https://beardocs.baylor.edu/xmlui/bitstream/handle/ 2104/7926/ mark_boone_phd.pdf?sequence=1 (last time accessed: July 5, 2016).

${ }^{7}$ Augustine, Contra academicos. Against the Academics and The Teacher, trans. Peter King (Indianapolis: Hackett Publishing, 1995), II,2.3.

${ }^{8}$ Ibidem.

${ }^{9}$ Augustin, Contra academicos, II, 2. 4.

${ }^{10}$ See also: Augustine, Confessions, trans. Henry Chadwick (Oxford: Oxford University Press, 1991), 6.14.24.
} 
called natural resources for philosophy: they act like an inner light that breaks through into our life no matter how dark our vices might be eventually. If these natural conditionings of the soul are corrupted, philosophy allows a restoration of the affects to their original state, good by nature but currently corrupted. Augustine is arguing for this position by advancing the idea that even an enemy would recognize the call of beauty, such strong and standing it is, so there is a "good fate" in a sense, a privileged moment when no matter how hopeless our fall had been, a good direction appears in mind, reflecting the good order of things, a good fate that is actually the "religion" one has been taught in his early youth. When in deep sorrow, religious education from our childhood springs about as a distant call equivalent to philosophy in a way, as we instantly become concerned with the searching for the meaning of life. There is such a confession in Contra academicos:

"Now I confess that I looked back on the religion implanted in us as boys, binding us from the marrow, as though from a long journey's end. Yet it was actually drawing me to itself without my realizing it. And so stumbling, hastening, hesitating I snatched up the Apostle Pau1. Truly, I declared, the [apostles] would not have been able to do such great deeds, nor would they have lived as they clearly did live, if their books and arguments were opposed to so great a good. I read all of it with the greatest attention and the greatest care." 11

The search for beauty has such a power of attraction that even the greatest adversary - so a character opposed to Romanianus in all the aspects - would be transformed into a philosopher. This condition is depicted by Augustine in a luxurious manner with the help of an urban image very familiar to his own youth:

"Then, no matter how little the light was that had already been cast by the visage of philosophy, it now appeared [philosophiae facies apparuit] so great to me that if I could show it to (...) your adversary, he would rush to its beauty as a passionate and holy lover, admiring and breathless and exhilarated. He would forsake and abandon his fashionable resorts, his pleasant orchards, his luxurious and elegant banquets, his household performing troupe; and, in the end, he would shun whatever strongly inclines him to all kinds of pleasures. We should admit that even your adversary has a certain beauty of spirit - or rather we should admit that he has a seed of beauty, so to speak."12

"Philosophiae facies apparuit" (philosophy's face will show), is an expression that comes from Plato's Phedrus, where beauty is identified with wisdom and, according to Pierre Courcelle, it offers its lovers an image of herself ${ }^{13}$. The Platonician place has been quoted by Cicero two times. Thus there is an inseparable connection between the corrupt nature of emotions dominated by a juvenile unfulfilled love of beauty and the search for the meaning of life. The Platonic scala amoris is the grounding for the Augustinian urging depicted above: public bathrooms, orchards, and all the enumerated delights, disappear from our mind like magic when the "seed of beauty" erupts. It will eventually grow twisted and deformed through the darkness of vices and the "brambles of fallacious opinions". But finally some people, "the few acute and diligent viewers in bushes" will be able to thrive through the bush of deceitful opinions and acquire the brilliance, elegance and sophistication of a superior beauty, the true philosophy: "It's straining to blossom forth into true beauty, but it sends forth only twisted and misshapen shoots among the rough underbrush of vices and the brambles of fallacious opinions. Yet it continues to bloom and to exhibit itself, as far as it is able, to those who peer keenly and intently into the thicket. From this source comes his hospitality; the civility that seasons his banquets; his elegance, charm, sophisticated taste in all things; and his urbanity that everywhere sprinkles all things with traces of loveliness. This is commonly called 'philocaly." 14

\footnotetext{
${ }^{11}$ Contra academicos, II.2.2.4.

${ }^{12}$ Ibidem.

${ }^{13}$ Pierre Courcelle, "Le visage de Philosophie," in Revue des Études anciennes 70 (1968): 110-120. See also: H.-I. Marrou, Saint Augustin à la fin de la culture antique (Paris, 1958), 100 (and notes 21-22, page 112).

${ }^{14}$ Augustin, Contra academicos, II.2.2.4.
} 


\section{Determinant cause of encountering love for wisdom: philocaly}

The connection between philosophy as love of wisdom and philocaly as love of beauty is a recurring Platonic motif ${ }^{15}$ assumed by Augustine. Following in the footsteps of Plato's Symposium, the theory presented in these fragments is that human desires are naturally perverted by the inclination towards futile, apparent and transitory beauty of everyday routine attractions, but only wisdom is truly beautiful. ${ }^{16}$ Our desires must be cultivated towards wisdom, for that which we commonly call love of beauty may be an intermediate love, alienated, poorly directed, that must be elevated by climbing of the whole scale of platonic Eros in order for it to become a prime or paradigmatic love. Otherwise, our natural capacity to love a certain thing has only the meaning of the early Eros, serial and quantitative. Justly we can ask, together with the philologist Haruko Momma, ${ }^{17}$ if we think further to this median level, is it possible that we take into account other kinds of love, as the love for honors (philotymia), or the love of hospitality (philoxenia), as worthy terms of a similar comparison to philosophy. Or, we may eventually ask, following Plato in his Parmenides, whether the speck of dust or mud or garbage can be the object of $\operatorname{love}^{18}$. Still, this love for honors, hospitality or even dust or mud, are explicitly discussed in the Platonic tradition. Augustine himself is well aware of the rejection, in Plato's Republic of such attractions. The theme of love for beauty is nevertheless part of the yet Platonic tradition theme of conversion to philosophy: the antique world conversion means explicitly a conversion to philosophy. With Augustine and the Christian tradition afterwards, conversion will signify the returning to God, more exactly to Christ or, as in the later developments, the Virgin Mary ${ }^{19}$. Not always will this mean a returning to solitude, as in Philon, but the returning to God is nonetheless equivalent to the turning to oneself, as the self is the image of God. ${ }^{20}$

Now, the love for beauty as a natural inclination (amor pulchritudinis), as alienated, ${ }^{21}$ gives us basic deeds that must be cultivated towards practicing philosophy (love of wisdom - amor sapientiae), because wisdom only is indeed beautiful ${ }^{22}$. The following fragment from Contra academicos [II, 2.3.7] is the most important for our discussion: "This is commonly called 'philocaly.' Do not condemn the name because it's common (ex vulgi nomine)! Philocaly and Philosophy are nearly the same names (prope similiter cognominatae sunt) and they want to be seen as members of the same family, as in fact they are. What is Philosophy? The love of wisdom (amor sapientiae). What is Philocaly? The love of beauty (amor pulchritudinis). (Just ask the Greeks!) What, then, is wisdom? Is it not true beauty (vera pulchritudo) itself? Hence they are sisters born of the same father.68 Although Philocaly was dragged down from her heights by the birdlime of lust and kept in an ordinary cage, she retains the close resemblance in her name to remind the birdcatcher not to despise her. Her sister, flying freely, often sees her in a debased and needy condition with her wings clipped. She rarely sets her free. Philocaly does not know from what origin she springs; only Philosophy knows that."23

\footnotetext{
${ }^{15}$ See: Mark J. Boone, The Conversion and Therapy of Desire in Augustine's Cassiciacum Dialogues.

${ }^{16}$ See: Plato, Symposium, 204b.

17 Haruko Momma, From Philology to English studies. Language and Culture in the Nineteenth Century (Cambridge: Cambridge University Press, 2013), 3.

${ }^{18}$ Cf. Plato, Parmenides, $130 \mathrm{c}-\mathrm{d}$ "What about these, Socrates? That things might seem absurd, like hair and mud and dirt, or anything else totally undignified and worthless? Are you doubtful or not you should say that a form is separate for each of these, too...?". Trans. Mary Louise Gill and Paul Ryan, in Plato, Complete Works (Indianapolis: Hackett Publishing, 1997).

${ }^{19}$ Virgin Mary will be named Superphilosophata by Egbert of Schönau, and Odon of Cantorbery will see in Virgin Mary the "philosopher of Christians". Apud M.-M. Davy, Initiation medievale. La philosophie au douzième siècle (Paris: Bibloiothèque de l'Hermetisme Albin Michel, 1980), 110.

${ }^{20}$ See: M.-M. Davy, Initiation medievale, 169 sq.

${ }^{21}$ See: Mark J. Boone, The Conversion and Therapy of Desire in Augustine's Cassiciacum Dialogues.

${ }^{22}$ As in Plato's Symposium, 204b.

${ }^{23}$ Augustine, Contra academicos, II 2.3.7.
} 
Augustine is offering this fragment as a fable ("I have suddenly become an Aesop!" - he continues) and recalls the figure of the adversary, the reversed character (lover of false beauty) who, even for one moment, would necessarily take refuge in philosophy, embracing Romanianus as he would recognize him as brother. Thus the allegory says that any human being situated under the influence of false beauty (philokalia) will instantly recognize the authenticity and superiority of philosophy; not only that: the cosubstantiality ("brotherhood") of philocaly and philosophy.

The common element between philosophy and philocaly is philein: both are based upon subjective determination of the contemplated object; but, again, as in Plato's Symposium, beauty is originally postulated by the arbitrary judgment of the subject: beautiful is what gives us pleasure ${ }^{24}$, hence the failure of vulgar philocaly in obtaining authentic beauty. For the same reason, the Augustinian excerpt is also a critique of Manichaeism: the Manicheans cannot transcend the sensible beauty of phantasms (phantasmata) $)^{25}$ and thus the worship of phantasms (mental images) as idolatry ${ }^{26}$. Nature has specific resources, let's call them inclinations, which predispose to seeking beauty. In Concerning the nature of good we find out that even in the "body of a monkey there is inscribed a good of beauty, but a smaller one," and that the presence of this natural good is the very condition for the possibility of both reducing and growing the good and the beautify within us:

"But that what we have said may be understood, and may satisfy those too slow of comprehension, or that even the pertinacious and those repugnant to the most manifest truth may be compelled to confess what is true, let them be asked, whether corruption can harm the body of an ape? But if it can, so that it may become more hideous, what diminishes but the good of beauty? Whence as long as the nature of the body subsists, so long something will remain. If, accordingly, goodhaving been consumed, nature is consumed, the nature is therefore good." 27

This inherited nature and tendency to look for the relative good, beauty or pleasure, is a limitation, in the sense that we can be misled and believe that good, beauty or pleasure of corporeal nature are sufficient. However, while it is the poor sister of philosophy, philocaly acts as well as condition of possibility for obtaining wisdom, to the extent to which only through her can we find balance or moderation that represents the beginning of overcoming the stage of vulgar inclination for relative beauty. Wisdom itself is a measure or moderation (modus), a balance of the soul. ${ }^{28}$ When soul lacks balance, it is called a sick soul: it suffers either from excess (marked by luxury, despotism, pride), or from lack (poverty, fear, anger, or addiction):

"Therefore, to be happy means nothing else than not to be in want, that is, to be wise. (...) Wisdom is nothing but the measure of the soul, that is, that through which the soul keeps its equilibrium so that it neither runs over into too much nor remains short of its fullness. It runs over into luxuries, despotism, pride, and other things of this kind, through which the souls of immoderate and miserable men believe they get joy and might. But it is narrowed down by meanness, fear, grief, passion, and many other things through which miserable men make acknowledgement of their misery. However, when the soul beholds the wisdom found and (...) devotes itself to it, and, without being moved by mere empty vanity, is not seduced to the treachery of images, weighed down in whose embrace it generally deserts God and finds a pernicious end, it then fears no immoderateness, and therefore no want and hence no misery. Thus, however, is happy possess his measure, that is, wisdom." ${ }^{29}$

\footnotetext{
${ }^{24}$ Kam-Lun Edwin Lee, Augustine, Manichaeism and the Good (doctoral dissertation, 1997), 76-77. Available at: https://www.ruor.uottawa.ca/bitstream/10393/9773/1/NN19983.PDF (last time accessed: July 14, 2016).

${ }^{25}$ See: Ibidem, chapter 1, section 4.1.

${ }^{26}$ See as well: Confessions, IV, II, 3.

${ }^{27}$ Augustine, On the Nature of Good, trans. Albert H. Newman. From Nicene and Post-Nicene Fathers, vol. 4. Ed. Philip Schaff (Buffalo: Christian Literature Publishing, 1887), 15.

${ }^{28}$ See: Lee, Augustine, Manichaeism and the Good, 77, footnote 125.

${ }^{29}$ Augustine, "De Vita Beata," in The Fathers of the Church: Saint Augustine. The Happy Life, Answer to Skeptics, Divine Providence and The Problem of Evil, Soliloquies, trans. Ludwig Schopp (New York: Catholic University of America Press, 1948), IV.33.
} 
On balance, it is prone to health, so to wisdom (temperantia et frugalitas) having a modus dictated by moderate pleasure. But how can someone be cured from this mediocre or trivial condition of desire for minor beauty, phantasms and idols? In De ordine, at the end of the first book, during a morning conversation between Augustine and Licentius, followed by a cockfight, we find out that, in some way, it is not entirely up to us; just similarly to the role of religious learning mentioned in Contra academicos (discussed above), here it is shown that only God can heal our desires and that we should pray for it. During this discussion, at some point, Augustine and his dialogue partner are singing from the Psalms (,,O God of hosts, convert us. Show us your face and we shall be saved (Psalms, 79:8-9)", and now Licentius finds even the love of poetry as being repulsive, at least for that "poetry" that Licentius calls the very dialectical debate he and Augustine have: "You couldn't have done me a better turn. Whether it is a typical boyish fickle change of heart at which you may laugh, or something truly induced by a divine command, let me tell you: I have suddenly lost interest in all this poetry. (...) I swear that philosophy is much more attractive than Pyramus, Thisbe, Venus, and Cupid, and such like amorous stories"30.

However, Augustine brings into the question the subject of order: what we need to find balance is to impose order upon ourselves, shifting from excess or lack of moderation regarding vices to temperance.

"If you care about order, you should go back to those verses. Instruction in the liberal arts, in moderation and to the point, produces lively, persevering, and refined lovers of truth. Their aim is ardently to desire, constantly to pursue, and eventually lovingly cling to what is called, Licentius, the happy life. Mention happiness, and all stand up, hands extended, to beg of you some alms as if they were poor wretches in the grip of disease. But as wisdom begins to demand that they take themselves to the physician and let themselves be cured by him, they return to their rags. Wasting away in the warmth of their rags, they scratch the itchy scabs of troublesome lust rather than submit to the physician's prescriptions. These are hard at first, but effective against the disorder, so that with a little endurance and submission they would be restored to health and to the light of understanding." 31

\section{The capacity to love wisdom}

The path that we can use in order to impose order to our desires is the way of the liberal arts: they help us to get closer to the truth and to a happy life, by guiding our hearts to the love of God, the only doctor who heals our desires. Nevertheless, the role of the physician works as an allegory for the master philosopher.

The problem of philosophy as synonym to Christian wisdom depends though on the distinction between trivial or pagan philosophy and the philosophy of Christian doctrine. In the second debate of the Book I of De ordine, Augustine distinguishes between pagan philosophy ("the philosophers of this world"), which misses out on wisdom, so this isn't amor sapientiae, respectively the philosophy of those who truly love wisdom, that of those who follow Christ, the only one that can heal the sick soul. He starts by translating the Greek word philosophia into Latin and obtains amor sapientiae ("Philosophy is a word of Greek origin meaning love for wisdom"). The problem remains to establish what sapientiae is for him and for the pagans respectively:

"That is why scriptures, which you love so much, do not enjoin to avoid and make fun of all philosophers without distinction but of philosophers of this world (sed philosophos huius mundi ${ }^{32}$ ). Christ himself makes the distinction between this world and another far removed from it, when saying: My kingdom is not of this world (de hoc mundo). He does not say: My kingdom is not of the world (regnum meum non est de mundo). Whoever condemns philosophy as a whole, condemns nothing less than wisdom itself. If you were not a lover of wisdom, I would despise you in my writings. I would not despise

\footnotetext{
${ }^{30}$ Augustine, De Ordine, trans.Silvano Borusso (South Bend: St. Augustine's Press, 2007), Book I, First Debate, 8.21 .

${ }^{31}$ Augustine, De Ordine, 8.24.

${ }^{32}$ See: John of Salisbury, "Metalogicon," in The Metalogicon of John of Salisbury: A Twelfth-Century Defense of the Verbal and Logical Arts of the Trivium, ed. Daniel D. McGarry (Berkeley: University of California Press, 1955), 18.36 .
} 
you, however, were you to love it even half-heartedly (si eam mediocriter amares). Much less would I do such a thing if you loved wisdom as much as I do. As a matter of fact you love it far more than you love me, and do I know how much you love me! You love it so much, indeed, that neither setbacks of any kind nor death itself holds any terror for you. The learned are of the opinion that to achieve this most difficult state is the inner core of philosophy itself. Should I not therefore be your willing disciple?"33.

Therefore there are two kinds of philosophy. First, there is the philosophy of this world, which is to be avoided and made fun of (as it is stated in the Bible, Colossiansi 2.8), that of the sick souls who cannot see the path to the paradigmatic beauty and restraint themselves through their own weakness to thinking of lust for corporeal beauty. Second, there is the true philosophy of the healthy souls, healed by Christ the doctor, able to desire beyond the lust, the authentic beauty.

One's access to the very distinction between these two, and perhaps to the road from one to another, is conditioned by the quality or rather capacity to love. There are three levels of such capacity.

The first level is of of those who do not love wisdom (non amare sapientiam), who condemn wisdom as a whole and are, in their turn, contemptible ("contemnerem te si sapientiam non amares", "If you were not a lover of wisdom, I would despise you in my writings"). These haters of philosophy or antiphilosophers, are in fact suffering of an illness or unbalance, either by excess (luxury, despotism, pride) or by deficiency (poverty, fear, anger, or addiction), and should be healed by the doctor. They are identical to those lovers of beauty in the trivial sense, described in Contra academicos, as we have seen above, as enemies of Romanianus. Not only should they be considered ill but they need to encounter the destined moment of sorrow in order to reach their inner educational ground, that distant call of Christ, which Augustine confesses again in De ordine II.2.4. (see above): "Now I confess that I looked back on the religion implanted in us as boys, binding us from the marrow, as though from a long journey's end."

Second, there is the level of those who are literally loving and searching for wisdom in a mediocre manner; or, should we say, searching for beauty in a superior manner. They should not be despised ("I would not despise you, however, were you to love it even half-heartedly") but on the contrary considered as proper students or disciples. They have discovered their natural gift for philosophy but remain mediocre or half-hearted, just like Romanianus did, before receiving that most precious gift, the master's (and friend's, which are interchangeable terms here, but this is another subject) invitation to practice philosophy.

The first and the second stages are most probably able to be identified with two kinds of philocaly: first is the trivial love of beauty (for fashionable resorts, pleasant orchards, luxurious and elegant banquets, household performing troupe, in sum, inclination of pleasures), and the second is what Augustine described in the same fragment as a liberation and blossoming of the hidden seed into the true beauty, though "twisted and misshapen" from among the "rough underbrush" of "vices and fallacious opinions". It is the second and superior meaning of philocaly that springs hospitality, civility, elegance, charm, sophisticated taste, urbanity and loveliness ${ }^{34}$.

Third, there are those who love wisdom fully, in an educated manner: they are not frightened by any shortcomings nor by death itself; this is the very core of philosophy, and these are worthy to be followed as masters ("Should I ... therefore be your willing disciple").

\section{Liberal arts}

In synthesis, the way this love of wisdom is formed by the master is somewhat a path that starts from our bodily nature, with its natural predeterminations towards pleasure, continues with the love for sophisticated things and eventually reaches the love of truth, of perfection. The instrument that Augustine mentions several times for facilitating this turn from philocalia to philosophia consists in teaching the liberal arts. They impose order upon our desires, help us approach truth and happiness, and are meant to direct our habitudes towards order and temperance. We remember, Licentius had said that after the

\footnotetext{
${ }^{33}$ Augustine, De Ordine, 11.32.

${ }^{34}$ See again Augustine, Contra academicos, II.2.2.4.
} 
revelation he had he found poetry and Pyramus, and Thisbe, and Venus, and Cupid, and such like amorous stories, as disgusting; Augustine had answered: "If you care about order, you should go back to those verses. Instruction in the liberal arts, in moderation and to the point, produces lively, persevering, and refined lovers of truth. Their aim is ardently to desire, constantly to pursue, and eventually lovingly cling to what is called, Licentius, the happy life". The balance or moderation needed for pursuing wisdom, procured by the liberal arts, are the soul's health, equivalent to the love of wisdom.

After Augustine, we surprisingly encounter a similar discussion in John of Salisbury. He was engaged in a similar direction in his Metalogicon, but inserted philology as a third term next to philocaly and philosophy, calling them sisters or allegorical figures of reason, beauty and wisdom. In Salisbury's case we can find a similar strong connection between wisdom, reason and beauty, the love for them being called inclination as they can only be perfect in the presence of God, so rightfully named like that; in the case of human beings they appear as imperfection or at most as relative perfection. That is why people do not seek reason, but the love of reason or philology, the love of wisdom (sapientia) or philosophy and love of beauty or philocaly. ${ }^{35}$ Although human imperfection cannot afford to promise itself wisdom, reason and beauty, still the search never ends. Prudence (phronesis), as the aptitude for the pleasures of the appetite, is the one that chooses the inclination for reason, wisdom and beauty as being desirable and thus gives us an appetite or craving for that which is true and good. ${ }^{36}$ Thereby, this search goes on as a continuous inclination until, gaining experience through the contribution of grace, she finally obtains the objects of this inclination.

Philocaly and philosophy set up an upward path, a scale from nature to spirit. Love of beauty, as a natural endowment, is both a restriction and a ground or sign towards the boundlessness offered by the love of wisdom; this inner road we must cover from philocaly to philosophy bears the irreducible particularity of the unique person that each of us is, thus fulfilling an experience of the self. Besides the liberal arts, the classical divisions of philosophy ${ }^{37}$ originate in the need to organize the study according to an itinerary through the internal path that must be accomplished by the philosopher. This structured effort requires a complete transformation of the person's vision and attitude.

\section{References}

Augustine. "On the Nature of Good." Trans.Albert H. Newman. In Nicene and Post-Nicene Fathers, vol. 4., ed. Philip Schaff. Buffalo: Christian Literature Publishing, 1887. . Against the Academics and the Teacher. Trans. Peter King. Indianapolis: Hackett Publishing, 1995.

. Confessions. Trans.Henry Chadwick. Oxford: Oxford University Press, 1991.

. De Ordine. Trans. Silvano Borusso. South Bend: St. Augustine's Press, 2007.

"De Vita Beata." In The Fathers of the Church: Saint Augustine. The Happy Life, Answer to Skeptics, Divine Providence and The Problem of Evil, Soliloquies, trans. Ludwig Schopp. New York: Catholic University of America Press, 1948.

Boone, Mark J. The Conversion and Therapy of Desire in Augustine's Cassiciacum Dialogues. Umi Dissertation Publishing Proquest, 2011 (available at https://beardocs.baylor.edu/ xmlui/bitstream/handle/ 2104/7926/ mark_boone_phd.pdf?sequence=1 - last time accessed: July 14, 2016).

Courcelle, Pierre. "Le visage de Philosophie.” In Revue des Études anciennes 70 (1968).

Davy, M.-M. Initiation medievale. La philosophie au douzième siècle. Paris: Bibloiothèque de l'Hermetisme Albin Michel, 1980.

\footnotetext{
${ }^{35}$ John of Salisbury, Metalogicon, IV, 38.

${ }^{36}$ Ibidem, IV, 29.

${ }^{37}$ See: P. Hadot, "Les divisions des parties de la philosophie dans l'Antiquité," in Études de philosophie ancienne, (Paris: Les Belles Lettres, 2010), 125-158.
} 
Florenski, Paul. La colonne et le fondement de la vérité, trans. Constantin Andronikof. Paris: L'Âge d'homme, 1975.

Hadot, Pierre. "Les divisions des parties de la philosophie dans l'Antiquité." In Études de philosophie ancienne. Paris: Les Belles Lettres, 2010.

John of Salisbury. "Metalogicon," In The Metalogicon of John of Salisbury: A Twelfth-Century Defense of the Verbal and Logical Arts of the Trivium, ed. Daniel D. McGarry. Berkeley: University of California Press, 1955.

Lee, Kam-Lun Edwin. Augustine, Manichaeism and the Good. Doctoral dissertation, 1997. https://www.ruor.uottawa.ca/bitstream/10393/9773/1/NN19983.PDF (last time accessed: July 14, 2016).

Marrou, H.-I. Saint Augustin à la fin de la culture antique. Paris: Éditions E. de Boccard, 1958.

Momma, Haruko. From Philology to English studies. Language and Culture in the Nineteenth Century. Cambridge: Cambridge University Press, 2013.

Plato. Complete Works, ed. John M. Cooper. Indianapolis: Hackett Publishing, 1997.

Sancti Avrelii Avgvstini. Contra academicos. De beata vita. De ordine. De magistro. De libero arbitrio, Corpus Christianorum Pars II, 2, Tvrnholti Typographi Brepols Editores Pontificii, MCMLXX.

Thucydides. History of the Peloponnesian War. II.40, ed. Benjamin Jowett. Perseus Project.

Xenophon. "Cyropaedia." In Xenophon in Seven Volumes, ed. Walter Miller. Cambridge: Harvard University Press, 1914. Perseus Project. 